\title{
IAMJ
}

INTERNATIONAL

AYURVEDIC

MEDICAL JOURNAL

ISSN: 23205091

Impact Factor: 5.34

\section{EFFECT OF MUSTADI UPANAHA AND TAILA DHARA IN AVASCULAR NECROSIS OF HIP JOINT: SINGLE CASE STUDY}

\author{
$\underline{\text { Sarmah Jyoti Manab }}{ }^{1}, \underline{\text { Mahor Bharti }}^{2}, \underline{\text { Arse Reshma }}^{3}, \underline{\text { Kumar Pravesh }}^{4}$ \\ ${ }^{1}$ P.G. Scholar, ${ }^{2}$ P.G. Scholar, ${ }^{3}$ P.G. Scholar, ${ }^{4}$ Associate Professor \\ Department of Panchakarma, Rishikul Campus, Uttarakhand Ayurved University, Uttarakhand, India
}

Corresponding Author: reshmaarse0473@gmail.com

\section{https://doi.org/10.46607/iamj4008092020}

(Published online: September 2020)

Open Access

(C) International Ayurvedic Medical Journal, India 2020

Article Received: 07/07/2020 - Peer Reviewed: 01/09/2020 - Accepted for Publication: 01/09/2020

Check for updates

\begin{abstract}
Avascular necrosis is a disease in which cellular death of bone component occurs due to interruption of the blood supply. Bone fractures, joint dislocations, alcoholism and long-term use of steroids are the commonly found risk factors of the disease. The disease generally happens in 35 to 60 years old population and commonly affects hip joint. About 10,000 to 20,000 people usually develop osteonecrosis of head of femur yearly in United States. This case deals with a diagnosed case of avascular necrosis of the femoral head in a 68 years old female. Patient had been suffering from pain in the left hip joint since 5 years. She had been under allopathic conservative treatment for her complaints, but symptoms aggravated rapidly since 4 months. So, for further management, she came to Out Patient Department of Panchakarma, Rishikul Campus where three sittings of local application of Mustadi Upanaha on left hip region along with Taila Dhara with Dhanwantaram Taila was performed. After three sittings, she got significant relief in joint pain and her quality of life. The assessment was done based on both subjective as well as objective parameters after each sitting. This study reveals that Panchakarma procedure like Mustadi Upnaha, Taila Dhara provided a significant relief in this case.
\end{abstract}

Keywords: Avascular necrosis, Mustadi upanaha, Taila Dhara Panchakarama 


\section{INTRODUCTION}

Avascular necrosis also known as osteonecrosis is characterised by osseous cell death due to vascular compromise. Ischemia of the bone tissue occurs leading to infarction which further cause necrosis due to lack of oxidative phosphorylation. Body tissues need oxygen for proper functioning, without which there is impaired metabolic functioning. Avascular necrosis of bone results generally from corticosteroid use, trauma, SLE, pancreatitis, alcoholism, gout, radiation, sickle cell disease, infiltrative disease, (e.g. Gaucher's disease), and Caisson disease ${ }^{1}$. AVN is multi-factorial but can begin with interruption of blood and oxygen supply to vasculature in and around bone and progresses to trabecular thinning (also seen in cases of osteoporosis) and eventually, collapse of bone. The most vulnerable site is the femoral head. The site of necrosis is usually immediately below the weight bearing articular surface of the bone (i.e. the anterolateral aspect of the femoral head). This is the site of greatest mechanical stress.

This patient presented with avascular necrosis of left hip joint with pain referred to the left thigh and knee. The possible cause in this case was history of fall down and left without medical management. It appears that this avascular necrosis may have been initially overlooked.

Radiological features of osteonecrosis generally involve collapse of the articular cortex. Fragmentation mottled trabecular pattern, sclerosis, subchondral cyst, and/or subchondral fracture. This patient's radiographs demonstrated the presence of irregular outline in left femoral head with sclerosis. Bilateral hip joints spaces were reduced (suggestive of avascular necrosis of left head of femur and osteoarthritic changes of right head of the femur).

Treatment is mainly surgical and generally involves a total hip replacement or arthroplasty for end-stage femoral head osteonecrosis using either a cemented or cement less prosthesis. Cemented total hip arthroplasties have been reported as being inferior with high failure rates in younger patients and in patients with femoral head necrosis because of their inferior durability.
Avascular necrosis can be compared in Ayurveda as Vatavyadhi. Symptoms mainly mimic to the Asthimajjagata Vata Lakshanas. Here Ruksha, Laghu, Vhala Gunas of Vata gets diminished. Thus, the case presents the clinical features as Sandhisool, Bhedo Asthi-parvanam, Satata ruk, Mamsa bala Kshaya and Aswapna $^{2}$ which correlate the symptoms of Aascular necrosis.

\section{Case Report}

A female patient of 68 years old having complaint of difficulty in walking upstairs and severe pain in left hip region radiating to thigh in any posture since last 4 months. Patient has been suffering from same complaints (mild to moderate intensity) since 5 years. She had undergone conservative treatment from allopathic hospital for the same. Lastly, her symptoms aggravated since 4 months hampering day to day activities. So, for further management, she came to Out Patient Department of Panchakarma, Rishikul Campus. She was nondiabetic, no history of hypertension, thyroid problem. There was neither history of trauma nor other medical or surgical illness as well as no history of long use of steroids etc. But, she had a history of fall down on hip 7 years back. She was bed ridden out of pain for 3 days, relieved by selfmedication (pharmacy, home remedy). Obstetric history was $\mathrm{G}_{4} \mathrm{P}_{3} \mathrm{~A}_{1} \mathrm{~L}_{3}$. Patient had often taken allopathic medicine for her pain from pharmacy (selfmedication).

The Patient, resident of Haridwar, Uttarakhand an elderly lady of Muslim community from middle class family. She is habituated to non-vegetarian diet with addiction to tea (4/5 cup daily) and paan (3/4 daily). Appetite is normal. Bowel habit and micturition is normal. She attained menopause 21 years back. Other features of general examinations are within normal limit. There is no family history noted for the same complaint. On examination the basic parameters such as B.P. (130/80 $\mathrm{mmHg})$, Pulse rate $(76 / \mathrm{min})$, Respiratory rate $(22 / \mathrm{min})$, Heart rate $(76 / \mathrm{min})$ are within normal limit. Pallor, icterus, cyanosis, edema, dehydration, were absent. No local lymphadenopathy, clubbing noted. On systemic examination, 
cardiovascular, respiratory, central nervous system, gastrointestinal system and urogenital system are found within normal limit.

\section{Musculo-skeletal system:}

Patient had painful limping gait. She was more comfortable to walk with support. There was no anatomical deformity detected in spine and upper extremities. Mild pain and tenderness were noted in sacral region, left hip region radiating upto left thigh. No swelling, no redness, no muscle atrophy was noted. Painful, restricted movements (all directions) were noted in left hip joint. Muscle power was noted 5/5 in bilateral legs.

During Dashavidhparikshaya Bhava examination, patient was observed as,

Pakruti: Kapha-Vata; Vikriti: Vata predominant; Sara: Medasarata in Pravar; Mamsa in Madhyam; Rasa, Rakta, Asthi Majja, Shukrasarata in Avar matra;

Samhanana: Madhyam; Pramana: Madhyam; Satmya: Madhyam; Satva: Madhyam; Ahara shakti: Avara; Vyayama shakti: Avara; Vaya: Vriddhavastha; Samprapti Ghatak; Dosha- Vata; Dushya- Rasa, Rakta, Asthi, Majja; Srotas- Asthivaha, Majjavaha; Agni- Vishamagni, dhatwagni manda; RogamargaMadhyam; Sadhyasadhyta- Yapya/ ashadhya

The patient was suspected of avascular necrosis of the left hip joint with differential diagnosis of hip osteoarthritis, healed fracture. Radiological study revealed that there was avascular necrosis of left hip joint. The cause of the disease was not quite sure, risk factors were elderly overweight (86 k.g.) women with menopause. She had a past history of indirect injury to the hip joint. Patient was advised for surgical intervention, but she was not interested in surgery. She gave us written consent to continue with Ayurvedic management.

\section{Intervention}

Treatment was planned after considering Samprapti and Doshik assessment of both Roga and Rogi. Mustadi Upanaha, Taila dhara was applied in three sittings, each sitting was of 21days. Taila Dhara was performed by Dhanwantaram Taila in the morning time for 30 min and Upanaha was being tied in the evening time. 14 days of interval was chosen after each sitting.
Follow up of the patient was done after completion and starting day of each sitting. The final follow up was done on $105^{\text {th }}$ day of the treatment schedule. Vitals were checked each day prior to the therapy.

Ingredients of Mustadi Upanaha

A) Fine Churna of Musta, Surakitta, Til, Kustha, Devdaru, Tagar in equal amount

B) Saindhav Lavan Q.S.

C) Cow's milk Q.S.

D) Curd (cow) Q.S.

E) Chatursneh (Ghrit, Taila, Vasa, Majja in equal amount) ${ }^{3}$ Q.S.

Preparation/ Procedure of application of Mustadi Upanah

The above-mentioned contents are mixed together and cooked under medium flame until it becomes semisolid form. The material was applied in the affected part, in 4 Angula diameter covered with Eranda Patra and finally tied with cloth. The Upanah Dravya is to be removed after 6 hours and then the part to be washed with lukewarm water.

\section{Ingredient of Dhanwantaram Taila}

For the whole study prepared Dhanwantaram Taila ${ }^{4}$ was taken.

\section{Procedure of Taila Dhara}

In this patient Pradeshik Taila Dhara with lukewarm $\left(38^{0}-40^{\circ} \mathrm{C}\right)$ Dhanwantaram Taila was poured from Dharapatra from 4 Angula distance for $30 \mathrm{~min}$. After the procedure the part was cleaned, and she was advised for hot water bath in the next hour.

\section{Observation and Result}

Treatment plan of therapy was for 105 days. Patient was treated in three sittings each of 21 days, 14 days interval was advised after each sitting. All the subjective as well as objective parameters were noted accordingly. Pain was significantly reduced, whether tenderness was relieved comparatively late to the pain (table No.1). Pain was assessed by Visual Analogue Scale( Fig No. 1) Walking performance of the patient was significantly improved (table No.1). Range of movement of the affected hip joint were measure with Goniometer (table No.2), where marked improvement was noticed 
Table 1: Assessment Criteria

\begin{tabular}{|l|l|l|l|l|l|l|l|}
\hline & Day 0 & Day 21 & Day 36 & Day 57 & Day 71 & Day 92 & Day 105 \\
\hline Pain & 8 & 5 & 4 & 4 & 3 & 2 & 1 \\
\hline Tenderness & +++ & +++ & ++ & ++ & ++ & + & + \\
\hline Walking steps in 1 min & 10 & 18 & 24 & 30 & 58 & 64 & 80 \\
\hline
\end{tabular}

Table 2: With Goniometer (In Degree)

\begin{tabular}{|l|l|l|l|l|l|l|l|}
\hline Left Hip & Day 0 & Day 21 & Day 36 & Day 57 & Day 71 & Day 92 & Day 105 \\
\hline Flexion & 60 & 72 & 78 & 84 & 84 & 94 & 100 \\
\hline Extension & 4 & 6 & 6 & 8 & 10 & 12 & 12 \\
\hline Internal rotation & 10 & 12 & 12 & 18 & 18 & 24 & 26 \\
\hline External rotation & 10 & 12 & 12 & 16 & 18 & 20 & 22 \\
\hline
\end{tabular}

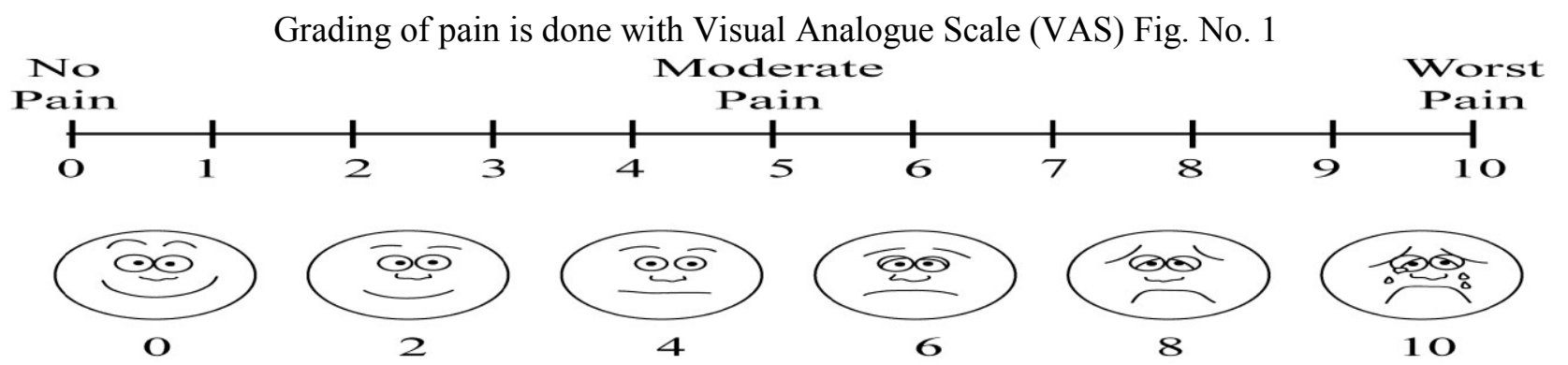

Patient was followed up after 5 months. There was no mentioning of deterioration of the sign and symptoms by the patient. The treatment improved her quality of life.

\section{DISCUSSION}

Avascular necrosis is characterized by osseous cell death due to vascular compromise. Avascular necrosis of bone results generally from corticosteroid use, trauma, SLE, pancreatitis, alcoholism, gout, radiation, sickle cell disease, infiltrative disease, (e.g. Gaucher's disease), and Caisson disease. The most commonly affected site is the femoral head and patient is usually hip and referred knee pain. This patient presented with avascular necrosis of left hip with pain referred to the left thigh. The possible cause in this case was history of fall down and left without medication. It appears that his avascular necrosis may have been initially overlooked.

Taila Dhara and Upanah are the type of Swedan karma. In both the therapies combined effect of Snehana and Swedana is attained. The basic differences are Taila Dhara is more Snehana than Upanaha, whether in Upanaha the contact time is more. More ever, the ingredient of Dhanwantaram
Taila pacifies mainly Vata Dosha whether Mustadi Upanah embeds with Vata Shamak and Brimhana quality.

Upanah is a treatment module in Ayurveda which comes under Swedan Karma. It is categorized under both Sagni and Niragni Swedan. Taila Dhara is a Bahyopkrama/bahiparimarjan Chikitsa explained under Dravasweda. Both the Therapies are Vata samak, by virtue of its Ushna, Ssnigdhaguna. It combats with the properties of Vatadosha like Sheeta, Ruksha, Laghuguna. The Swedana are mainly of Guru, Ushna, Tikshna and Sukshma quality. By virtue of these qualities drug enters the Dhatus one by one i.e. Rasa, Rakta, Mamsa, Medaasthi, Majja and Sukra. Ushna, Tikshna Gunas of drug intensify the Dhatwagni. The Swedan Karma itself clears the Srotas of the body. Ushna, Tikshna, Sara and Sukshma properties of drugs opens up the Srotas which are under obstruction. Out of four Tiryak Dhamanis, each one is divided into hundred and thousand times thus become 
innumerable. These supply the body like network and their openings are attached to Roomakupa. Virya of Bahya Chikitsa like Upanaha etc. enter into the body after undergoing Paka by Bhrajak Pitta in the skin.

\section{CONCLUSION}

Avascular necrosis is a debilitating condition affecting day to day activities. As the disease is prevalent in elderly age the treatment should be cost effective, comfortable for the patient and with nil to minimal side effect. Panchakarma is a ray of hope in managing such cases. The present study sets an example in management of avascular necrosis. It can improve the quality of life of the patient.

\section{REFERENCES}

1. Shah Kn, Racine J, Jones Lc, Aaron Rk, Pathophysiology and Risk Factors For Osteonecrosis. Curr Rev Musculoskeletal Med. 2015;8 (3):201-209. Doi: 10.1007/S12178/S 12178-015-9277-8.

2. Charak Samhita, Vidyotani Hindi Commentary by Kashinath Shashtri, Seventh Edition, Chikitsa Sthan, Chapter 28, Verse No. 33, Chaukhamba Sanskrit Sansthan, 2002. Page 782.

3. Charak Samhita, Vidyotani Hindi Commentary by Kashinath Shashtri, Seventh Edition, Chikitsa Sthan, Chapter 28, Verse No.112, Chaukhamba Sanskrit Sansthan, 2002. Page 798.

4. Sahasra Yoga, Taila Prakaran (1) 74, Dhanwantaram Taila

\section{Source of Support: Nil \\ Conflict of Interest: None Declared}

How to cite this URL: Arse Reshma et al: Effect Of Mustadi Upanaha And Taila Dhara In Avascular Necrosis Of Hip Joint: Single Case Study. International Ayurvedic Medical Journal \{online\} 2020 cited September, 2020\} Available from: http://www.iamj.in/posts/images/upload/4544_4548.pdf 